\title{
The Use of Semantic Mapping Strategy to Improve Students' Skill in Writing Descriptive Texts: a Classroom Action Research (CAR)
}

\author{
Nurul Akbar ${ }^{*}$, Yulitriana ${ }^{2}$ \\ ${ }^{1}$ SMK Muhammadiyah Karangampel; ${ }^{2}$ The University of Palangka Raya
}

\begin{abstract}
Writing is a complicated skill should be mastered by students as it requires some knowledge related the purpose of the text, generic structure, and language features as well as the skills to organize the ideas and information in a logical way by keeping the unity and coherence of the text, so the piece of writing will be easily understood by the readers. Therefore, some students at the tenth grade of SMK Muhammadiyah Karangampel experience difficulties in writing a text, especially in writing descriptive texts. In order to improve the students' skills in writing descriptive texts, the teacher applies semantic mapping strategy. The result shows that there is improvement in students' scores after the treatment as semantic mapping technique facilitates their needs to brainstorm and organize ideas and information.
\end{abstract}

Keywords: semantic mapping strategy, writing skill, descriptive text

\section{INTRODUCTION}

Language is a tool to communicate various intentions and purposes to fulfil life's needs. It highlights how important language mastery as a life skill to survive. Therefore, the implication of learning English is hoped to improve students' skills in creating both spoken and written English according to their literacy development level.

One of the skills students should master is writing skill. Yet, creating an English text which is accordance with the English culture is not easy for students as universally there are different mind-sets among nations. A writer should understand the social and cultural contexts of the native speakers as the background. In this case, English context has produced different types or genres with different purposes of communication. Therefore, since 2004, English education in Indonesia is based on different types of English genres or texts and adjusted to the education level.

One of text types which should be mastered by students at Senior High School is descriptive text. This text is used to describe people, things, or places and can be parts of other texts such as narrative or report texts, and as a result, the skills in descriptive text writing is prominent.

In the tenth grade, the problem students encounter when they write descriptive texts is their low skill to arrange and organize information. Neither can they can write with coherence nor can they write with well-organized and logical structure. As the consequence, the students' scores in writing descriptive text are low. Their average scores are 57. In order

\footnotetext{
*Corresponding author: nurulakbar88@gmail.com

To cite this article: Akbar, N., \& Yulitriana (2022). The Use of Semantic Mapping Strategy to Improve Students' Skill in Writing Descriptive Texts: a Classroom Action Research (CAR). Ebony --- Journal of English Language Teaching, Linguistics, and Literature, 2 (1) 2022, pp. 28--36.
} 
to solve this problem, the researchers try to apply semantic mapping strategy in learning descriptive text. Therefore, the problem of this research can be formulated as the following: "Can the use of mind mapping strategy improve students' skills in writing descriptive text?" Mind mapping is used as the solution for the students' problems.

Accordingly, the objective of the research is to improve students' skills in writing descriptive texts at the tenth grade of SMK Muhammadiyah Karangampel Indramayu Regency. Thus, it is hoped that this research can give significance for both the students and teachers. For the students, they will find it easier to organize ideas or information they have in writing descriptive text in accordance with the generic structure of the text. For teachers, they will know more exactly about their students' needs and problems; furthermore, they then can give the solutions for the problems.

\section{LITERATURE REVIEW}

In this part, the review of theoretical concepts used as the research background. The theoretical concepts written in the sub-chapters are about semantic mapping and skills in writing descriptive text.

\section{Semantic Mapping}

Semantic mapping comes from the words "semantic" and "map." Hurford and Heasley explains that semantics is "the study of meaning in language" or knowledge that learns about language meaning.(Hurford R. \& Heasley, 1983) On the other hand, "mapping” comes from the word "map" which means "peta" in Indonesian.

The following are some definitions of semantic mapping used in education:

a. "Semantic mapping generally refers to brainstorming association which a word has and then diagraming the result." (p.22).(Takac, 2008)

b. "Semantic mapping is a technique that can be used in all disciplines to demonstrate the relationships between ideas." (Gaut, 2002)

c. Semantic mapping consists of vast categories of graphic organizers which can be used in various discussions to help students understand the connection and build concepts about broad topics. (Huynf et al., 2002)

d. Semantic mapping has great impact on students' vocabulary knowledge because it can motivate them to create lexical network among word. (Abdelrahman, 2013)

According to the definitions above, semantic mapping is a graphic or diagram that present verbal ideas. These ideas consist of main ideas which are the subjects will be discussed and sub-ideas describe the subjects. These sub-ideas can be in the form of words or phrases which are connected one another. Generally, main ideas are positioned in the middle which are then divided into sub-topics. These ideas can be put in circles, boxes, or triangles. Semantic mapping can also be in the form of ideas tree in which the main idea is in the stem while the sub-ideas are in the branches. Elaboration of the sub-ideas are in the twigs.

The following is an example of a semantic mapping from a subject "My Father" 


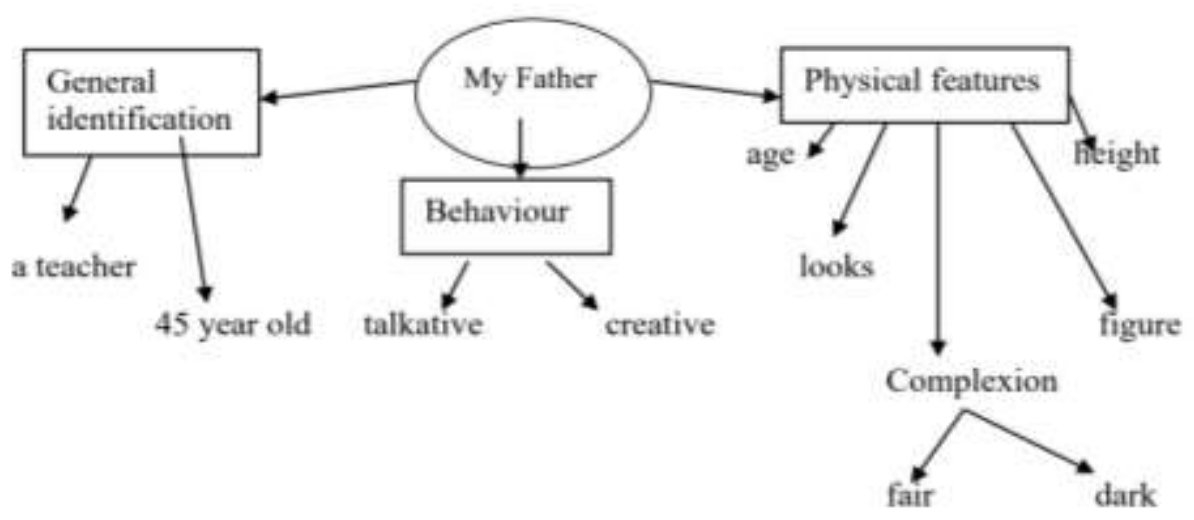

Figure 1. Semantic Mapping from the subject My Father

(Modified from Board of Studies NSW, 1994:2004)(NSW, 1994)

Students can develop the above diagram according to the information they have. Words or phrases under the main idea or subject function as the sub-ideas and as topic sentences for each paragraph. Furthermore, words or phrases under the main idea are detailed information supporting topic sentences for each paragraph.

\section{Writing Skill}

Writing skill is an ultimate goal or main competency should be achieved by high school graduates. Writing skill needs a complicated process in which the researchers have to make a plan and modify his or her writing based on some aspects such as diction, grammar, unity or harmony among the supporting sentences and the main idea in the paragraph resulting in the complete meaning of the paragraph and coherence or presenting well-organized ideas, both for the topic and supporting sentences (Smalley and Hogue, 1986). The order of information in the descriptive texts are based on the generic structure of the texts.

The book of English standard competency states that a descriptive text is a text with the purpose to describe the characteristics of someone, a thing, or a place. The generic structure consists of introduction of the thing being described and then followed by some descriptions about the characteristics of the thing, such as colour, size, etc. This description just gives information about specific thing or person being described. The language features of this text are the use of a specific noun, using simple present tense, detailed noun phrases, adjectives, relating verbs, thinking verbs, action verbs, and adverbials.

\section{Framework}

According to the literacy level, students of high school are targeted to achieve informational level which emphasizes reading skill. As students are prepared to continue to university level or to interact directly in their social life; therefore, it is also important to improve their writing sill. Students should know the rhetorical steps in organizing the texts.

The fact shows that students' skill in organizing ideas or information in descriptive texts is still low. They tend just to combine various information they get from different sources without considering the coherence and generic structure of the text. Hence, their texts are not written systematically and become convoluted. It is difficult for the readers to know the topic for each paragraph. 
The researchers try to find the way to help students organizing their ideas and information they have on certain subject, so they can create a descriptive text with correct generic structure and clear topic for each single paragraph. Moreover, information is presented chronologically and logically. Semantic mapping can be used to facilitate students' need in organizing meaning ideas and information within a text.

Based on the review of related literature above, it can be predicted that semantic mapping can improve students' skills in writing descriptive texts. Thus, the hypothesis for this action research is by using semantic mapping strategy, it can improve students' skills in writing descriptive texts at the tenth grade of SMK Muhammadiyah Karangampel.

\section{METHOD}

\section{Research Setting}

This research was conducted at the tenth grade of TKRO SMK Muhammadiyah Karangampel which consists of 28 students. A classroom action research was conducted in this school as the students had low skills in writing descriptive texts. The average score for writing in groups was 57 with the Score of minimal passing criteria was 70 . The students had problems in organizing ideas and information systematicall and logically and apply the generic structure of the texts. The actions were conducted 4 times. (4 time 90 minutes).

\section{Research Subject}

The subject of this research are the students of tenth grade TKRO SMK Muhammadiyah Karangampel Indramayu Regency.

\section{Source of Data}

The source of data for this research are as the following:

a. Cognitive test about the students' knowledge about descriptive text.

b. Writing test (scoring rubric is attached).

c. The result of questionnaire distributed to students to find their responses towards the learning of descriptive text writing in this research.

d. Interview conducted by collaborators to find out their responses and opinion towards during the research. Technique of data collection is intended to know the students' need, especially in descriptive text writing activities.

e. Result of observation conducted by the collaborators during students' group work. The purpose is to know their attitude during the group activities and the effectiveness of mind mapping strategy in facilitating the students during descriptive text writing.

f. Teacher's diary. Teacher's diary contains the notes of students' action and reaction and all the things happen during the research.

\section{Technique of Data Collection}

a. Giving a cognitive test to find out about students' knowledge of descriptive text before the treatment/action.

b. Giving worksheet for the written test of descriptive text

c. Giving questionnaires before and after the research action.

d. Interview 
e. Observation

\section{Instrument for Data Collection}

a. Cognitive test questions. Students' worksheet to write a descriptive text

b. Questionnaires' questions. Questionnaires given before the treatment/action, after the first and second cycles.

c. Interview Guideline. The students who are interviewed are chosen randomly from each group.

d. A graph that shows the result of all cycles.

e. Observation sheet filled in by collaborators. Observation is conducted to take notes of students' attitude during the group work based on the guidelines provided by giving tally (V) in the columns provided.

\section{Data Validity}

a. Cognitive test and student' worksheet are tried out to students who are not the subject of the research.

b. Questionnaire validity is also conducted, similar to the cognitive test in point a,

c. Validity of the result of questionnaire is conducted by having collaborators in the interview activity.

d. Validity of observation sheet is conducted by involving the senior teachers who know whether the observation sheet is already the representative of the data will be collected. Data triangulation is conducted by involving collaborators.

\section{Data Analysis}

a. The average score of the result of cognitive test about descriptive text is taken and analysed descriptively.

b. Students' writing is scored based on the aspects in the scoring rubric, such as content and format, organization and coherence, vocabulary and sentence order. Afterward, the result is analysed descriptively and comparatively by comparing test scores both among cycles and working indicators.

c. The results of questionnaires before and after the action/treatment in cycles I and II are analysed descriptively.

d. The result of interview is analysed descriptively.

e. The result of observation by collaborators is analysed descriptively to know the students' condition and activity during the learning process in the research.

\section{Research Procedures}

\section{Planning}

In the planning step, some activities were taken such as looking for sources related to semantic mapping strategies, descriptive text, learning cycle as well as the Content Standard in English learning.

In this step, following activities were done:

a. Making research timetable

b. Making lesson plans

c. Making cognitive test questions for individual 
d. Choosing the topic and subject will be developed

e. Making students' worksheet

f. Making a scoring rubric to assess students' writing

g. Making questions for questionnaires and interview

h. Making observation sheet

\section{Action}

It was carried out an action research in the step of joint construction of text (JCOT) in the writing cycle. In this step, students start writing a descriptive text with their group. The explanation for the purpose or social function of descriptive text, exercises for the simple present as the language feature, explanation and the use of technical terms, the use of relational verbs and material verbs have been given in the previous step which is Building Knowledge of the Field (BKOF). Giving examples of descriptive text has also been given in step of Modelling of the Text (MOT). In MOT step, both teacher and students analyse text based on the language features and the steps of writing rhetorical. The purpose is students can identify and understand sentences using present tense patterns, technical terms about the subject, and relational and material verbs. Therefore, in the step of JCOT, the students are able to write a descriptive text even in their small group and by the teacher's assistance.

The following is the explanation on how researchers applied the semantic mapping strategy as the treatment for the problems in the cycle.

$>$ The teacher invites the students to discuss about a familiar topic for them, such as about a human with the subject "My father." In order to get information from the students, the teacher gives some questions related to family members until finally one student mentions about one of the family member they love the most, for example "My father."

$>$ Next, the teacher writes the words "My father" on the whiteboard; then, he mentions explicitly about the subject will be discussed. Relevant information related to the subject can be obtained from the students according to the knowledge they have to build a semantic mapping. Teacher writes words or phrases from the students on the whiteboard. Based on the generic structure of descriptive text, it is usually started with "identification." The word "love" can be used to start the paragraph, for example: "I love my father very much." The word "best" can also be included in the opening statement, for example: "He is the best father in the world." Therefore, the words "love" and "best" can be placed under "My father" as the general statements about "My father."

$>$ In the next step, the teacher can ask the students to give information related to more detailed description of their father. In this step, the teacher helps the students to get used to organize information systematically.

$>$ Next, the students continue to work on the first sub-idea, for example is about the physical features. In order to help students to find information related to physical features, the teacher can show keywords, such as "age, figure, looks, complexion."

$>$ Afterward, the teacher and students can add words more specifically for each keyword. For instance, for the word "age", the teacher can ask students to mention words related to age, such as "young, old, middle-age." The same activity is continued for the other keywords, so the students can have a description about what they have to write in each sub-idea. 
From the explanation above, we can form a semantic mapping as the following:

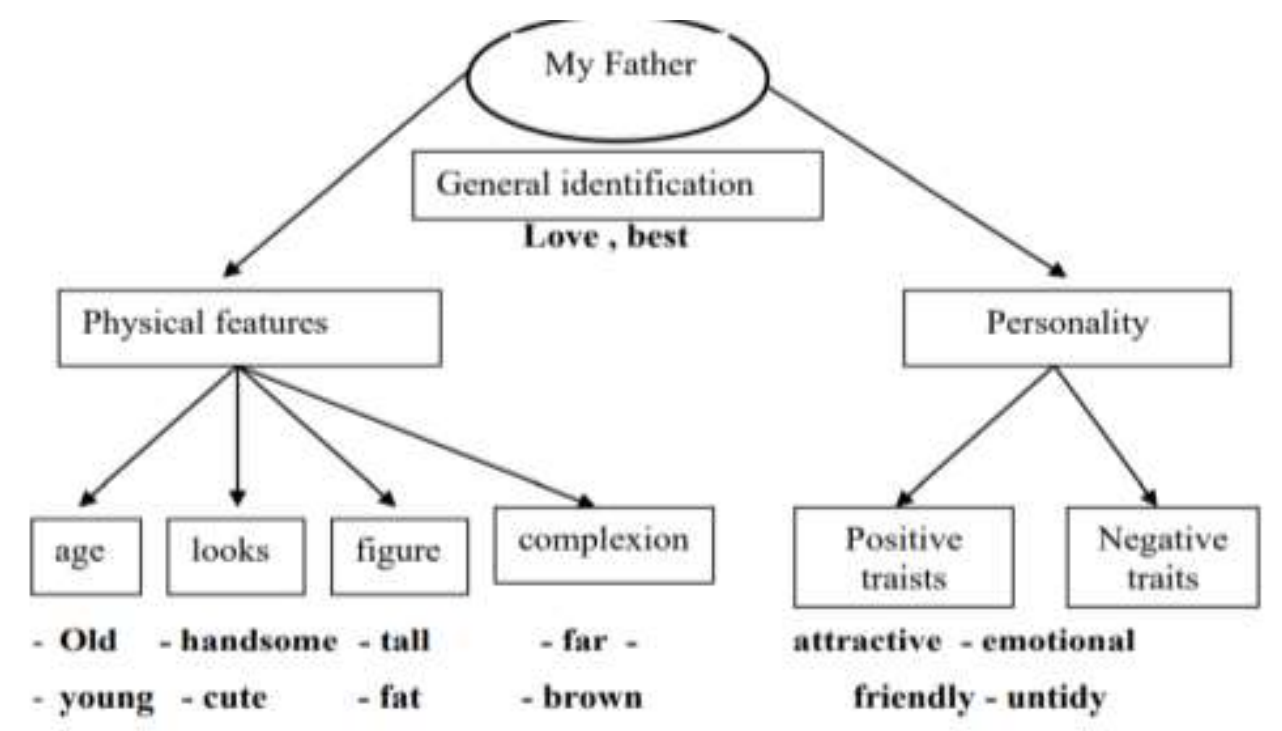

Figure 2: Semantic Mapping for the subject "My father"

Notes:

a. The circle shows the subject being discussed.

b. The squares show the sub-ideas will be developed as topic sentences for each paragraph in the opening, series of description, and the closing.

c. Words or phrases under the squares show elaboration from the sub-ideas as detailed information.

The students are hoped to be able to organize information into a simple descriptive text as the above example. After being given this action, the students start working in their group according to the subject chosen. Furthermore, the type of action given in the next cycle depends on the difficulty or problems the students face in writing descriptive text after action in the first cycle.

\section{Observation/Evaluation}

Observation or evaluation on the development of students' skill is conducted in every treatment phase. The data are analysed descriptively. The program as a whole is evaluated based on feedback the feedback from the result of data analysis.

\section{Reflection}

After having detailed description of the success and the obstacles experienced in implementing this semantic mapping strategy, the researcher continued the research by repeating from the planning step. If the result of the first cycle is not satisfying, then the researcher will do some revision or modification to continue in the next cycle.

\section{RESULT}

The following is to present two types of data: the result of first cycle and the second cycle from 28 students of SMK Muhammadiyah Karangampel. 


\section{First cycle}

The result of first cycle shows that the minimum score is 9 and the maximum score is 65 . According to the category in class interval, the distribution result of frequency and percentages of students' score in first cycle at the tenth grade of SMK Muhammadiyah Karangample Indramayu Regency is in the low category as most of the students, 19 students or $47 \%$ students are included in the low category. The researchers conclude that their scores in first cycle before being given treatment is in the low category.

\section{Second cycle}

The result of second cycle shows that the minimum score is 14 and the maximum score is 78. According to the category of class interval, the distribution result of frequency and percentages of students' score in second cycle at the tenth grade of SMK Muhammadiyah Karangample Indramayu Regency is in the good category as most of the students, 21 students or $52 \%$ students are included in the good category. The researchers conclude that their scores in the second cycle after being given the treatment is in good category.

\section{DISCUSSION}

Based on the data findings, some interesting facts are found. The first, students' skill in the low category can be found out from the majority of the students (19 of the 40 students or $47 \%$ ) are included in the low category as the scores they get in the first cycle are low as 33 as the limit.

The second, the students' skill at the tenth grade of SMK Muhammadiyah Karangample Indramayu Regency is improved after the treatment. It is found out that most of the students ( 21 of the 40 students or $52 \%$ ) are included in the fair category as the scores they get in the second cycle are improved as 33 as the limit.

The indicator of success in applying semantic mapping strategy in learning descriptive text writing in this research is that the scores of students' descriptive texts improve from the average of 57 into 72 .

Finally, according to the result discussed above, it can be concluded that the semantic mapping strategy can improve students' skill in writing descriptive text. Therefore, this research proves that semantic mapping has an influence to develop students' skill in writing, especially in writing descriptive texts.

\section{CONCLUSION}

The classroom action research on the effectiveness of semantic mapping to develop the students' writing skill at the tenth grade of SMK Muhammadiyah Karangample Indramayu Regency has significant influenced to develop students' writing skill. Before conducting the classroom action research, the researchers notified these following matters:

1. Most of the students are passive in the learning process.

2. Most of the students have low skill in writing.

3. Most of the students are not used to semantic mapping.

4. Most of the teachers find it difficult to motivate students to learn writing. 
Then, after conducting the classroom action research, the researchers found the following things:

1. The students are active in the learning process.

2. The students adapt the strategy to improve the writing skill.

3. The students get used with the semantic mapping.

4. The students have motivation to learn writing.

Based on the facts in this classroom action research, the researchers assumes that semantic mapping has influence to develop students' writing skill. The indicator can be observed from the result of post-test that most of the students, 21 students or $52,5 \%$ are included in good category and 7 students or 17,5\% are included in excellent category.

In relation to this result, some suggestions given to teachers related to the process in learning to write using semantic mapping at the tenth grade of SMK Muhammadiyah Karangample Indramayu Regency both for teachers and students. First for teachers: (1) teachers of English should motivate students to be interested in learning writing; (2) creative teachers should create interesting learning, so students can enjoy the teaching learning process; (3) teachers should know the difficulty in writing, so they can use appropriate technique to develop students' writing skill; (4) teachers should map difficult vocabulary, so students can comprehend difficult words; and (5) the use of good quality of English materials facilitates writing skills. Then, for students: (1) students should use good materials to improve their writing skills; (2) students should be more active and creative in the learning process; and (3) through the semantic mapping, students can get the main ideas a lot easier.

\section{REFERENCES}

Abdelrahman, A. M. (2013). The Effect of Teaching Vocabulary through Semantic Mapping on EFL Learners' Awareness of Vocabulary Knowledge at Al Imam Mohammed Ibin Saud Islamic University. International Interdisciplinary Journal of Education, II(7), $722-731$.

Gaut, R. (2002). Semantic Mapping Technique. Prentice Hall.

Hurford R., J., \& Heasley, B. (1983). Semantics: A Coursebook. Cambridge University Press.

Huynf, U., Lizaragga, L., \& Wilkerson, B. (2002). How do Semantic Maps Build Vocabulary.

NSW, B. of S. (1994). K-6 English Syllabus and Support Document. Board of Studies NSW.

Takac, V. P. (2008). Vocabulary Learning Strategies and Foreign Language Acquisition. The Cromwell Press Ltd. 